\title{
Applying the Process Approach in the Financial Service
}

\author{
K. I. Dairukina ${ }^{1} \&$ O. V. Demyanova ${ }^{2}$ \\ ${ }^{1}$ Kazan Federal University, Kazan, Republic of Tatarstan, Russia \\ ${ }^{2}$ Department of Production Economics, Institute of Economics and Finance, KFU, Kazan, Republic of Tatarstan, \\ Russia \\ Correspondence: K. I. Dairukina, Department of Production Economics, Institute of Economics and Finance, KFU, \\ Kazan, Russia. Tel: 7-987-675-7544.
}

Received: August 1, 2020

Accepted: September 15, 2020

Online Published: October 4, 2020

doi:10.5430/ijfr.v11n5p296

URL: https://doi.org/10.5430/ijfr.v11n5p296

\begin{abstract}
This article represents the utilization of the process approach in the financial service, as explained in the case of the Centralized Accounting Department of the City of Kazan Office of Cultural Affairs municipal public institution. The concept of process approach observes the activities of an organization as a set of interrelated processes. It is notable that evaluating the effectiveness of this approach's implementation is very significant. Only through the analysis of work processes can be stated as it affects the application of the measures described, leading to the subsequent development of the solutions to the problems that arise in the process of applying this approach in your organization, because the failure of one unit may lead to failure throughout the organization. It is important to note that the performance assessment performed within a single Department and described in this paper should be performed across all divisions. Because even by analyzing the processes, you can recognize issues and modify them in time. As such, the process approach is fundamental for such managerial concepts as logistics, production management, project management, quality management, and lean manufacturing philosophy. On the whole, we have attempted to recognize and eliminate losses in the process approach, which is a crucial step towards optimizing the organization's work.
\end{abstract}

Keywords: process approach, wastes, elements, methods, steps, tools, SADT, ARIS, BPMN, efficiency

\section{Introduction}

The study and implementation of the process approach should start with the term processes. A process is a set of interconnected activities that transform inputs into outputs using a particular technology, in other words, it is a repeated activity that produces a particular resource, which has value for the consumer.

The process approach was devised to facilitate effective quality control management.

The ISO 9001 standard on quality management systems formulates the implementation of the process approach as follows.

An organization should (Gostpiso, 2008):

1. Identify the processes that should be included in the quality management system and apply them throughout the organization;

2. Determine the sequence and interaction of these processes;

3. Determine and apply the criteria and methods (including monitoring, measurements, and related performance indicators) needed to ensure the effective operation and control of these processes;

4. Determine the resources needed for these processes, including information, and ensure their availability;

5. To monitor, analyze and measure these processes;

6. Evaluate these processes and implement any changes needed to ensure that the intended results are achieved.

An organization at its own discretion may delegate a process to a third-party organization; however, in this case it is to have control over such processes. The management of such processes is to be recognized in the quality management system (serenkov et al., 2020, Bayat, 2017).

In the process approach, there are a number of key elements, without which the implementation of this approach in an 
organization is rendered impossible: (Eliferov \& Repin, 2019)

- Input is an element which implies changes in the flow of a process;

- The output is a result at which the activities of a process are directed;

- Resources are elements required by the process. Resources are different from an input since they do not undergo changes within the process. Papers, staff, and finances are all considered resources;

- The owner of the process is a pivotal concept in the process approach. Every process has its owner, i.e. a person who has the required amount of resources, and is responsible for the end result (or outputs) of the process;

- Suppliers and consumers are inherent to any process. The suppliers are those who provide the sources of inputs, while the consumers are the receivers of outputs. It is important to note that a process has both external and internal suppliers and consumers. A process cannot be carried out without the suppliers, just as its outputs will not be demanded without the consumers;

- Process indicators are necessary to regulate the process, as well as to make decisions about possible issues. An indicator is a set of qualitative and quantitative parameters that are characteristic of the process and its result.

In order to successfully apply the process approach, process wastes should be identified. The wastes are those steps in a process that do not add or create value, but rather, they take it away from the final product, because wastes take up time, resources, and bear little significance in the process. According to the process management concept, works to eliminate these wastes should be carried out on an ongoing basis.

The following types of wastes are distinguished (apping \& Dunn, 2020):

1) Overproduction - the production of something before it is needed. This is the most dangerous type of waste, since it often entails other losses;

2) Waiting (queues) - the time wasted while waiting for people;

3) Motion - the movement of people or papers that does not create value. Thistypeofwaste is often caused by poor office management, outdated equipment, lack of the required resources.

4) Transport - the movement of papers that do not create value, but meddle with the time required by the office to perform a certain task.

5) Over-processing - the extra work that is required neither by the external nor the internal customer.

6) Inventory (time) - excess paper, stationery, or documents that require to be signed.

7) Defects -any work that has led to a defected product, including the work required to eliminate its flaws. This results in the worker spending less time trying to fulfill their task on the first try.

8) Inefficient use of workforce- i.e., as its situation where the workers are engaged in the work that is not suitable for their knowledge, skills, or experience.

These elements are necessary to describe the process. Without knowing these elements, it is impossible to construct an appropriate and high-quality process.

\section{Instruments and Methods}

The process approach applied at offices is called process office. It often promotes changes in how the most optimal model of organization processes is described and devised. It also helps make employees more aware of the process approach concept. Then, the processes are analyzed and optimized, which leads to a functional expansion within the organization. Thus, the process approach at the office or the process office unites the methodological practices for process improvement and performance indicators assessment.

The process office concept, in its essence, is a set of interacting processes that have end value for the organization or the internal consumer. In order to increase work efficiency at the organization, it is necessary to devise progressive approaches, which can only be done with the widespread implementation of the latest methods and technologies. Today, the following tools are thought to be the most commonly used ones: building a goal tree, goal decomposition, creating a balanced scorecard (Zhanuzakova, 2013).

In order to successfully implement the process approach at an organization, it is important to use professional tools that help describe and analyze business processes, as well as make them more manageable.

One of the most common methodologies is SADT (Structured Analysis and Design Technique). A subset of SADT is the IDEF standard, which, having automated support, makes itself affordable and easy to use. IDEF is a functional 
system model that allows one to represent a business process in the form of a system, subsystem, and their interrelated functions. In this model a system is viewed as a set of actions, each of which remodels an object or a set of objects (Repin, 2020).

Functional models highlight actions by having them presented in a function block. This block shows the function of a business process that is a central element of the IDEF notation. With the IDEF notation used, a model of the organization's functioning system appears, which consists of a set of dictionaries, diagrams, and records cross-referencing each other (Shastitko, 2004).

The ARIS (Architecture of Integrated Information Systems) instrumental system is a method that fully meets the requirements of the process approach. ARIS is a methodology and a family of software products developed by IDS Scheer AG (Saarbrücken, Germany) capable of providing a structured description of the process analysis, as well as improving the business processes of organizing and setting the grounds for the implementation of complex information systems.

The programs developed using the ARIS technology are applied at all stages of the business development - from developing an optimal organization strategy to making changes in the basic business processes, and from determining process costs to putting information systems into operation, as well as optimizing future activities.

The models that were created within the framework of the mentioned methodology are most relevant. The objectives of the project define the modeled simulation's level of indenture.

Another method to show business processes when creating workflow models is BPMN (Business Process Modelling Notation). This method aims to create a general notation of process models creation for various categories of specialists: from experts and analysts who model the processes of technical developers to managers who need to understand process diagrams in order to successfully solve the problems that could arise in the future. BPMN is what connects the initial stage of design with the final stage of implementation. (Repin, 2020)

As such, the process approach forms the basis for the development of a large number of techniques and approaches in the theoretical and practical aspects of organization management. Such methodological tools as optimization of business processes, scorecards, improvements in the management system, personnel motivation systems, information technology are the techniques used in process management.

\section{Results and Discussion}

Let us review the key stages of the process approach application in the financial services, as exemplified in the case of the Centralized Accounting Department of the City of Kazan Office for Cultural Affairs municipal public institution. (Serenkov et al., 2020)

Stage I. Preparations.

The objective of this stage was to gain perspective of the institution's outstanding problems:

- Redundancy in the manual input of data into software products (lack of information continuity) and errors that ensue;

- Lack of regulations on the relationship between the Centralized Accounting Department and its subordinate organizations, as well as the absence of standardized forms of documents for contracts celebration and financing the costs of contractual obligations;

- The formalized planning process, which requires constant adjustment and redistribution of the cash limit to subordinate organizations;

- Backward algorithm for making budgetary obligations, i.e., such obligations are made after the contract has been executed.

The following objectives were defined:

- To conduct optimization of the processes of conclusion, financing, payment and accounting of contractual operations by specifying the 'points' of data input/upload to different programs synchronization;

- To identify the ways to standardize operations with the contracts;

- To develop a system of financial and economic planning by mastering budgeting tools.

A working group was established as well. As a result, the organization attained a group of employees who clearly understood how the processes should work and saw the steps that had to be taken to bring this vision to life.

Stage II. "Unfreezing". At this stage the organ is a national structure, relationships within the office, and its work, in 
general, were analyzed.

The organizational structure of the Department has a pyramid structure with its top position being held by the highest-ranking manager, who distributes the entire work of the institution and delegates' responsibility for each segment of the overall task to department heads. The management makes use of uniform fixed norms and rules. These rules describe the rights and responsibilities of the employees and managers. The most basic provisions relate to the issue of defining the rights, powers, and responsibilities.

Stage III. Modeling of the As-Is Business Processes and Their Analysis. At this stage, the processes were modeled as-is, i.e. before their optimization. Then, the wastes were identified after the models of the existing processes had been constructed.

The information on wastes found at the Department is summarized in Table 1.

Table 1. The wastes in the centralized accounting department processes

\begin{tabular}{|c|c|c|}
\hline Waste & Cause & Effect \\
\hline $\begin{array}{l}\text { Redundant Manual } \\
\text { Input of Data Info } \\
\text { Software Products }\end{array}$ & $\begin{array}{l}\text { inability to perform a one-time input on data due } \\
\text { to the lack of information continuity }\end{array}$ & growing labor input \\
\hline \multirow{2}{*}{ Doubled Process } & inconsistent budget planning & \multirow{2}{*}{$\begin{array}{l}\text { Growing labor input; } \\
\text { late receipt of payments }\end{array}$} \\
\hline & errors during information input & \\
\hline \multirow{5}{*}{ Technical Restrictions } & uniform key to access the software (AZK-Web) & \multirow{5}{*}{ prolonged waiting } \\
\hline & incorrect segregation of duties & \\
\hline & inability to access AZK-Web & \\
\hline & Bars-Budget program restricted functionality & \\
\hline & technical capabilities & \\
\hline Approval & $\begin{array}{l}\text { lack of regulations on the relationship between } \\
\text { the Centralized Accounting Department and its } \\
\text { subordinate organizations }\end{array}$ & prolonged waiting \\
\hline Inventory & mandatory filing & costs to buy paper \\
\hline \multirow{2}{*}{ Defects } & errors when filling up forms & $\begin{array}{l}\text { Growing labor input; } \\
\text { late receipt of payments }\end{array}$ \\
\hline & $\begin{array}{l}\text { core software inconsistency } \quad(\text { AZK-Web, } \\
\text { Bars-Budget })\end{array}$ & $\begin{array}{l}\text { incorrect records in the book of } \\
\text { accounts }\end{array}$ \\
\hline $\begin{array}{l}\text { Unnecessary } \\
\text { Movements }\end{array}$ & $\begin{array}{l}\text { Movement of papers; inspections; off-line } \\
\text { retrieval of initial data }\end{array}$ & $\begin{array}{l}\text { Growing labor input; } \\
\text { late receipt of payments }\end{array}$ \\
\hline $\begin{array}{l}\text { Non-utilization of } \\
\text { Talent }\end{array}$ & incorrect planning processes & prolonged time of budget execution \\
\hline
\end{tabular}

Table 1 summarizes the wastes that were identified during the process building. In the left column, the wastes are shown, the "Causes" column describes what caused the losses, in the "Effect" section the result is described, that is, what the waste in question led to.

Other types of wastes were identified upon further analysis:

- Daily-made errors in the formation of contracts;

- Daily-made errors and subsequent returns of contracts from the Treasury due to lack of funds;

- on average, 5 employees a day were seen engaged in the chaotic movement of supplies within the Department due to unknown personal reasons (the managers did not know whom to contact for what information and how to provide data correctly). 
The above-mentioned wastes may indicate that the Department might have been suffering from misallocated responsibilities. Due to the heavy workload, the employees tend to make mistakes when hastily entering all the information into a computer program, possibly because of the low competence of employees, and also due to the lack of regulations for the processes.

\section{Stage IV. Target State Business Processes Modelling.}

At this stage, processes were building based on their desired state. Several different models were created, after which only two were selected: the ideal and the most suitable for the existing process. Then, measures for the transition from a simpler to the ideal option were identified. At this stage, proposals to optimize the process office were devised. The following proposals were highlighted at the Centralized Accounting Department:

1) Development of the working regulations for the Centralized Accounting Department;

2) Synchronization of the information on contracts present in the information systems;

3) Organization of the cost planning process for the subordinate organizations based on the forecast utilization of budget, with regard to the measures planned for future implementation;

4) Creation of a single work distribution center.

Implementations of these measures would optimize the processes, reduce waste, redistribute the workload between the employees, and ultimately lead to a successful implementation of the process office in the Department.

Stage V. Preparations and implementation of Changes in Processes, the Construction of a Process System in the Department. At this stage, a gradual introduction of the above measures takes place to improve performance and process regulation.

With the introduction of the process office, significant changes took place at the Centralized Accounting Department (Table 2).

Let us deeper investigate in Table 2 Contracts are processed by an economist of the Department of Procurement and Municipal Orders. In this table, the first column shows the time spent to register the contract in the information system, the second column is the time of registration after the optimization, and the third column is the time saved. As such, we see that efficiency has increased, amounting to $49 \mathrm{~min}$. Or $16.3 \%$. This is a significant change, since at the start of the optimization, the efficiency was just $8-10 \%$.

Table 2. Processing of contracts, min

\begin{tabular}{|c|c|c|c|}
\hline \multirow[b]{2}{*}{ Process } & \multirow{2}{*}{$\begin{array}{l}\text { The input of Data } \\
\text { into Computer }\end{array}$} & \multicolumn{2}{|l|}{ After Optimization } \\
\hline & & $\begin{array}{l}\text { The input of Data } \\
\text { into Computer }\end{array}$ & Effect \\
\hline 1. Below rub. 100K. Funds are available. & 40 & 35 & 5 \\
\hline 1. Losses-free. Below rub. 100K. Funds are available. & 20 & 15 & 5 \\
\hline 2. Below rub. 100K. No funds available. & 40 & 33 & 7 \\
\hline 2. Losses-free. Below rub. No funds available. & 20 & 17 & 3 \\
\hline 3. Over rub. $100 \mathrm{~K}$. Top priority. Funds are available & 40 & 38 & 2 \\
\hline $\begin{array}{l}\text { 3. Losses-free. Over rub. 100K. Top priority. Funds are } \\
\text { available. }\end{array}$ & 20 & 13 & 7 \\
\hline 4. Over rub. $100 \mathrm{~K}$. Top priority. No funds available. & 40 & 34 & 6 \\
\hline $\begin{array}{l}\text { 4. Losses-free. Over rub. 100K. Первоочередные. No } \\
\text { funds available. }\end{array}$ & 20 & 15 & 5 \\
\hline 5. Over rub. 100K. Non-priority expenses. & 40 & 34 & 6 \\
\hline 5. Losses-free. Over rub. 100K. Non-priority expenses. & 20 & 17 & 3 \\
\hline Total & 300 & 251 & 49 \\
\hline
\end{tabular}


After the implementation of the process office at the Centralized Accounting Department had taken place, several improvements were noted: the process efficiency increased, employees began to adapt to the renewed processes. However, some points still needed to be reviewed and upgraded.

\section{Findings}

In order to optimize the new processes, as well as to make sure that all actions go in order, it is necessary to devise performance indicators. Organization management efficiency is a relative character of the performance of a specific management system, which can be expressed with various indicators, both of the management object and of the management activity of the management subject.

Let us review Table 3, which presents the data on the effectiveness of the implementation of the process approach at the centralized Accounting Department. This table displays the savings from various types of contracts that the institutional processes.

Table 3. Saved time by type of contract, min

\begin{tabular}{|c|c|c|c|c|c|c|c|}
\hline \multirow[b]{2}{*}{ Type of Contract } & \multirow[b]{2}{*}{$\begin{array}{l}\text { Contracts } \\
\text { Per Year }\end{array}$} & \multirow[b]{2}{*}{ Before } & \multirow[b]{2}{*}{ After } & \multicolumn{4}{|l|}{ Saved Time } \\
\hline & & & & Per 1 Contract & $\begin{array}{l}\text { Yearly, } \\
\text { min. }\end{array}$ & $\begin{array}{l}\text { Yearly, } \\
\text { hrs. }\end{array}$ & $\begin{array}{l}\text { Yearly, } \\
\text { working } \\
\text { days }\end{array}$ \\
\hline $\begin{array}{l}\text { Competitive } \\
\text { Bidding }\end{array}$ & 22 & 624 & 601 & 23 & 506 & 8,433333 & 1,1 \\
\hline $\begin{array}{l}\text { Only Supplier } \\
\text { (On Exchange) }\end{array}$ & 201 & 128 & 75 & 53 & 10653 & 177,55 & 22,2 \\
\hline $\begin{array}{l}\text { Only Supplier } \\
\text { (Federal Law No. } \\
\text { 44, c. 4, c. } 5 \text { ) }\end{array}$ & 1164 & 71 & 38 & 33 & 38412 & 640,2 & 80,0 \\
\hline Total & & & & 109 & 49571 & 826,1833 & 103,3 \\
\hline
\end{tabular}

As a result of this analysis, it was discovered that, because of the optimization, the time to register a competitive bidding contract went down 23 minutes per contract, which enabled the organization to save 506 minutes, or 8.433 hours, or 1.1 working days per year. Further on, when registering a contract for a single supplier (on exchange), the time saved amounted to 53 minutes per contract, the annual savings were 10,653 minutes, or 177.55 hours, or 22.2 working days. The next type of contract is a single supplier (Federal Law No. 44, c. 4, c. 5). Here, 33 minutes were saved, the annual savings amounted to 38,412 minutes, that is, 640.2 hours, or 80 working days. Thus, we may conclude that, according to these figures, the effectiveness of the organization has increased.

Based on the presented data, a forecast was made (the main data are presented in Table 4 on the implementation of the proposal at the centralized Accounting Department.

Drawing on the conclusions of the forecast, we can say that the time saved on registering one contract, notwithstanding the time to approve it, would amount to $35 \%$ of the total amount of time spent prior to the introduction of the new approach. The average number of contracts will also be reduced by $10 \%$. The lead time for the contracts subject to approval will be reduced by $46.57 \%$. 
Table 4. Efficiency forecast on process approach application

\begin{tabular}{lllllllll}
\hline Process Name & \multicolumn{2}{l}{$\begin{array}{l}\text { Time of Contract Formation, } \\
\text { No Approval }\end{array}$} & $\begin{array}{l}\text { Average } \\
\text { Number } \\
\text { Contracts }\end{array}$ & $\begin{array}{l}\text { Yearly } \\
\text { of }\end{array}$ & $\begin{array}{l}\text { Time of } \\
\text { Approval Included }\end{array}$ & Fontract \\
& $\begin{array}{l}\text { Current } \\
\text { ly, hrs. }\end{array}$ & $\begin{array}{l}\text { Optimal } \\
\text { Value, } \\
\text { hrs. }\end{array}$ & $\begin{array}{l}\text { Time } \\
\text { Saved, } \\
\text { hrs. }\end{array}$ & $\begin{array}{l}\text { Current } \\
\text { ly, hrs. }\end{array}$ & $\begin{array}{l}\text { Optimal } \\
\text { Value, } \\
\text { hrs. }\end{array}$ & $\begin{array}{l}\text { Currently, } \\
\text { hrs. }\end{array}$ & $\begin{array}{l}\text { Optimal } \\
\text { Value, hrs. }\end{array}$ & $\begin{array}{l}\text { Time } \\
\text { Saved, } \\
\text { hrs. }\end{array}$ \\
\hline $\begin{array}{l}\text { Total Calculated } \\
\text { Process Labor }\end{array}$ & 120 & 78 & -42 & 2149 & 1934 & 223791 & 119568 & 104223 \\
Efficiency, hrs.
\end{tabular}

Thus, performance assessment is crucial for the implementation of the process office. Without this data, it would impossible to understand exactly how the implementation of the new tools influences the organisation'a activities, since a failure in one Department may interrupt the work of the entire institution.

\section{Summary}

Thus, we can conclude that identifying losses in the process approach is certainly an important step towards optimizing the organization's work. After eliminating the identified losses, the organization will be able to achieve the following:

1) Improve the quality of products or services;

2) Reduce the waiting time in the queue between operations;

3) Reduce the organization's costs;

4) To Increase the productivity of office work;

5) Encourage teamwork and involve employees in the process.

It is also important to evaluate the effectiveness of the implementation of the process approach. A comprehensive analysis of results is necessary for high-quality implementation, as well as for building an organization's development strategy to improve all existing low indicators.

\section{Conclusions}

The implementation of the process office forces the organization to review its managerial structure, hierarchy, and responsibilities. The success of such endeavors depends greatly on the leader and its objectives. It is also important to know the theoretical and practical aspects of the problem, since knowledge gives a better understanding of the current state of affairs, enabling one to make wise decisions aimed at eliminating the problem. Activities of an organization determine its strategic goals, processes within itself, and the interaction between these processes, and also establish the desired performance for each process and indicators with which it can be measured. It is vital to identify wastes not only during the construction of the processes themselves but also throughout all further activities. In order to achieve better performance, it is necessary to control the processes of an organization. At the same stage, it is important to constantly assess performance indicators. It should be noted that the works around processes increase the organization's controllability, making the organization think about its activities from the position of its very own client (both external and internal), and also contribute to the correct alignment of forces. (Eliferov \& Repin, 2019)

\section{Acknowledgements}

The work is performed according to the Russian Government Program of Competitive Growth of Kazan Federal University

\section{References}

Apping, D., \& Dunn, A. (2020). Berezhlivy' jofis: Ustraneniepoter' vremeniiudeneg. In A. Zalesova, \& T. Guran (Eds.), A publication in Russian (p. 320). OOO Al'pina Pablisher. 
Bayat, R. (2017). The Management of Capital Assets Life Cycle in Petrochemical Industry. Journal of Management and Accounting Studies, 5(02), 38-41.

Eliferov, V. G., \& Repin, V. V. (2019). Biznes-processy': reglamentaciyaiupravlenie: Uchebnik. Moscow: INFRA-M, 319.

GOSTPISO. (2008). Quality management systems, Requirements (p. 34). Moscow: Standartinform.

Holod, L. L., \& Hrustal'ev, E. U. (2017). Metodi I instrumentari'jrealizac'iiprocessnogopodhoda. Znanie Ponimanie Umenie, 4, 126.

Lisichkina, U. S., \& Sichev, U. K. (2017). Processni'jpodhod v upravleniiorganizacie'j. Upravlencheskienauki v sovremennom mire.

Repin, V. V. (2020). Biznespopravilam: reglamenty'dolzhny'rabotat'/prakticheskoeposobie. Moscow: INFRA-M, 167.

Saimoilova, A. N., \& Potapov, A. V. (2018). Processy' jpodhod $v$ sismeteocenkieffektivnostiupravleniyamalimpredpriyatiem. Sovremennietendencii $\mathrm{v}$ economikeiupravlenii: novy'jvzglyad.

Serenkov, P. S., Kur'yan, A. G., \& Volontej, V. P. (2020). Metody'menedzhentakachestva. Processny'jpodxod. Moscow: INFRA-M, 268.

Shastitko, A. E. (2004). Organizational framework of providing public services. Questions of Economy, 7, 155. https://doi.org/10.32609/0042-8736-2004-7-150-157

Zhanuzakova, L. T. (2013). Problems of definition of the concept «public service». The collection of materials of the republican sci-entific and practical conference "Constitutionalism and Problems of Ensuring Information Security in the Republic of Kazakhstan”. Almaty: Print-Master, 9-12.

\section{Copyrights}

Copyright for this article is retained by the author(s), with first publication rights granted to the journal.

This is an open-access article distributed under the terms and conditions of the Creative Commons Attribution license (http://creativecommons.org/licenses/by/4.0/). 